\title{
LIVING A PARASITIC LIFESTYLE. \\ Roma Population and the Policy of Systematisation in COMMUNIST TRANSYLVANIA
}

\author{
DIANA NISTOR ${ }^{*}$
}

\begin{abstract}
The systematisation policy was one of the more significant projects of the socialist leadership in Eastern Europe and the Soviet Union aiming at eradicating existing disparities between the centre and the periphery, and finally leading to the much desired 'socialist city'. In Romania, the "re-organization of settlements and territory" affected millions of people in urban and rural areas. This paper deals with the Roma marginal communities living in Transylvania during the communist years and the changes they encountered due to the systematisation process which, mostly in the 70s, explicitly targeted them because of their peripheral social behaviour, as they lived in "inappropriate neighbourhoods" and were practicing a parasitic lifestyle - considered harmful to the socialist society in the making. Some of the research questions to which the essay aims to provide answers are the following: Which were the peripheral dwelling conditions in the rural and urban areas in post-war Romania? When and how did the communist authorities decide to destroy peripheral Roma settlements? How do Roma remember forced displacement / forced residency (in case of the nomads) during the communist years? In order to give relevant answers, the research took as a starting point the archives and the post 1989 historiography. After that, an oral history approach was used to collect and recover life stories of Roma from Transylvania in the communist period which intends to complete the Romanian historical narrative.
\end{abstract}

Keywords Roma communities in Transylvania, systematisation, periphery, communist regime.

*Babeş-Bolyai University, Cluj-Napoca. sacarea.diana@gmail.com.

DOI: 10.26424/philobib.2021.26.2.08 
A particular concept of the image of Roma communities living in Transylvania during the communist regime was that of marginality. While strengthened by many exceptions, the rule of being located on the outskirts of settlements remained a reality - this is how the perception of a small Roma community settled nearby villages and towns appeared as "an inheritance" from the past. The essay deals with Roma marginal communities living in Romania and specifically in Transylvania during the communist years and the changes they encountered due to the policies implemented at the national and local level by the communist authorities. The following paragraphs focus on two issues that have led to changes in terms of the dwelling space Roma communities occupied during the communist era, namely: on the one hand, the alert urbanization and industrialization process that required an urgent development of the urban space in terms of housing and, on the other hand, the communist regime's "fight" against the parasitic lifestyle in all its forms as a factor which delayed the modernization of the socialist society in the making. In this sense, the following pages analyse the systematisation process which, at some point, implicitly targeted Roma communities in Transylvania due to their peripheral social behaviour, as they were living in "inappropriate neighbourhoods" and were practicing a "parasitic lifestyle." Furthermore, the communist policy of systematisation went hand in hand with the sedentarisation process of nomadic and semi-nomadic Roma. Some of the research questions to which the essay aim to provide answers are the following: which were, in the perception of the communist authorities, the factors that described a parasitic lifestyle? Which were the measures taken by the communist regime against social parasitism? How was the systematization project carried out in communist Romania and what was its purpose according to the Communist Party Programme? How were Roma neighbourhoods perceived by the communist local and central authorities? And finally: to what extent did the systematization process succeed with regard to the Roma population in the peripheral neighbourhoods? In order to give relevant answers, the research took as a starting point the National Archives and the historiography regarding the systematisation process in the 1970s. After that, an oral history approach was used to collect life stories of Roma in Transylvania which come to complete the Romanian historical narrative.

The present work intends to emphasize decisions adopted by the communist leadership in Romania in terms of the systematisation project and its stages during Gheorghe Gheorghiu-Dej and Nicolae Ceaușescu's leaderships. The first part focuses on some of the legal frameworks of the systematisation policy which offers a chronological and historical frame to the Roma testimonies regarding the measures they have witnessed. The second part addresses the manner in which the communist authorities in Romania have perceived and acted against "parasitism" and the parasitic lifestyle Roma people were practicing. The study conducted during the 1970s came to show the situation of Roma parasitic lifestyles 
around the country, offering solutions on the manner in which the regime should have dealt with these communities. Remembering the communist years, Roma interviewees made reference to the measures of demolition and/ or mass movements they have witnessed in the Roma neighbourhoods they were dwelling at the time. The third part of the essay emphasizes and examines the Roma people's perception of the systematisation policy, their testimonies describing the dwelling conditions in their neighbourhoods, the everyday lives of Roma residents of those neighbourhoods, the relationships with other ethnicities, their lives after the settlement was razed or, sometimes, the nostalgia expressed towards the communist regime. These testimonies come to emphasize the extent to which the communist rule succeeded or at least tried to accomplish the systematization of the territory and the eradication of social parasitism in all its forms until 1989.

\section{Urbanisation, industrialisation and systematisation policies during the communist regime}

In the context of urbanisation and industrialisation promoted by the communist regime, an interesting fact to approach is the manner in which Roma communities became, at some point, relevant to the communist authorities in terms of the policies applied in different periods. As Henri Lefebvre noted in his work, sometime in the 1920s a link was re-discovered which had already been dealt with on the practically but which had not yet been rationally articulated: that between industrialisation and urbanisation, between workplaces and dwelling places: "No sooner had this link been incorporated into theoretical thought than it turned into a project, even into a programme. The curious thing is that this 'programmatic' stance was looked upon at the time as both rational and revolutionary, although in reality it was tailor-made for the state - whether of the state-capitalist or the state-socialist variety. ${ }^{1 "}$ Therefore, industrialisation and urbanisation formed a dialectical unity as far as the industrialisation of the society implied urbanisation as well. In this sense, looking at the socialist urbanization - defined as a complex economic and social process through which the space evolves by replacing rural features with typical urban ones such as lifestyle, commercial relationships, educational system, etc. - it provides an excellent example of how state-socialist power imagined the landmarks of the "socialist life" through architectural projects. ${ }^{2}$

The systematisation policy was one of the most significant projects of the socialist leadership in Eastern Europe and the Soviet Union aiming at eradicating

\footnotetext{
${ }^{1}$ Henri Lefebvre, The production of space, translated by Donald Nicholson-Smith (Oxford: Basil Blackwell Ltd., 1991), 124.

2 Mara Mărginean, Ferestre spre furnalul roșu. Urbanism și cotidian în Hunedoara și Călan (1945-1968) (Iași: Editura Polirom, 2015), 14.
} 
existing disparities between the centre and the periphery, finally leading to the wished-for socialist city. In the Soviet Union, "national in form and socialist in content" conveyed the integration of the various regions of Soviet territory under a centralized authority to create a nation-state on the ruins of the former fragmented empire. Later, "national in form and socialist in content" rhetorically supported the exportation of the Soviet system into the newly-established Eastern European "popular democracies," as the USSR called them, and the construction of socialism atop the ruins of the war-devastated states. ${ }^{3}$ Following the pattern of the Soviet Union, Romanian authorities had implemented a series of urban development policies, among which, the policy of systematisation which focused on the "reorganization of settlements and territory." Urban systematization had to ensure an economically balanced and efficient development of the building infrastructure of cities, based on long-term development predictions, such as the five-year plans adopted during the communist regime. ${ }^{4}$ In Romania, the accelerated industrial development and the collectivization of agriculture during the 1950s and 1960s had important consequences not only in terms of economy but also at a social level, including the emergence of an accelerated migration phenomenon from the rural areas towards the urban industrial centres. ${ }^{5}$ This phenomenon produced a rapid increase of the urban population which could not be accommodated by the existing infrastructure at the time. In these circumstances, according to the official discourse, the urban systematization was to create the socialist city which had to be completely different from the capitalist city of the exploiting bourgeoisie in the interwar period - this new socialist city had to bring forward a place of equality and social equity, expressing after all the political regime's program. In this connection, all inhabitants of the socialist city were to gain equal access to educational, medical, recreational or transport services, regardless of their location, in the centre or at the outskirts of

\footnotetext{
${ }^{3}$ Mara Mărginean, Aesthetic Mechanisms of Stalinization in Romanian Architecture: The Case of Hunedoara, 1947-1954, A thesis submitted to the College of Graduate Studies and Research, University of Saskatchewan, Saskatoon, 12.

4 Ibid., 5.

5 There was a substantial redistribution of population between rural and urban areas taking place over the communist decades in Romania. In 1966 the rural population amounted to 11.8 million ( $61.8 \%$ of a total population of Romania of 19.1 million): the rural population was 61.4 $\%$ larger than the urban. However, in 1987 the estimated figure for the rural population was 10.48 million ( $45.7 \%$ of a total population for Romania of 22.94 million): the urban population was now 18.9 \% larger than the rural. Persistent migration has more than wiped out the natural increase, with the trends over recent years marking a further stage in the urbanization process which has been evident for a much longer period. (D. Turnock, The changing Romanian countryside: the Ceausescu epoch and prospects for change following the revolution, Environment and Planning C: Government and Policy, 1991, volume 9, 322-323).
} 
those settlements. ${ }^{6}$ Despite this political programme, an interesting issue to approach would be whether these intents were accomplished, or to what extent they were accomplished at the local level in Transylvania.

In order to make a brief presentation of the systematization programme in the 1950s and 1960s, it is notable that in 1952 at the USSR's pressures, in Romania the "socialist realism" " was imposed by adopting the decision of the Central Committee of the Romanian Workers' Party and the Council of Ministers on "Building and rebuilding the cities and the organization in the field of architecture." The establishment of the "State Committee for Architecture and Construction" in 1952 introduced the "socialist realism style of architecture. ${ }^{8 "}$ The next year, Stalin's death brought relevant consequences in the field of architecture within the Soviet Bloc countries: his successor, N. Khrushchev, denounced in 1954 the "socialist realism" in architecture, considering it to have wasted resources. His alternative solution was the implementation of policies with modernist accents based on standardization and industrialization of constructions with the main purpose of solving the housing crisis in the Soviet Union. Thus, two years after the implementation of socialist realism, Romanian architecture had to face major changes, establishing an optimal living space by standardizing dwelling surfaces. ${ }^{9}$

Beyond the communist propaganda aspect, the need of decent dwellings was an immediate necessity, given that many families (including the Roma) lived in poor homes in neighbourhoods without utilities and vital amenities. In this sense, many of the interviewees remembered that the city in which they dwelled during the communist regime ${ }^{10}$ had one or more Roma neighbourhoods (most of the time they made reference at streets where the houses were inhabited almost entirely by Roma). On the other hand, there was an urgent need of dwellings as long as, during the late 1940s and the beginning of the 1950s, the newly implemented communist authorities faced a severe "housing crisis."

After Nicolae Ceaușescu came to power, the systematization project was discussed within the official framework, at the National Conference of the Communist Party of Romania on December 6-8, 1967 (when the Governors presented proposals of "remodelling the rural environment") and at the 10th

\footnotetext{
6 Călin-Andrei Olariu, "Urban construction patterns in the city of Cluj, 1952-1965" in Studia Historia, Issue no. 2 (2015).

7 In this respect, the following institutions were created: The Institute for Urban Planning, Public constructions and Housing, The Institute for Industrial Construction Designs and The Union of Architects of the Romanian People's Republic. See also: Mara Mărginean, "Aesthetic Mechanisms of Stalinization in Romanian Architecture: The Case of Hunedoara, 1947-1954" ...

8 See Mărginean, Ferestre spre furnalul roșu. Urbanism și cotidian în Hunedoara și Călan (1945-1968)..., 96.

${ }^{9}$ See Olariu, "Urban construction patterns in the city of Cluj, 1952-1965" ...

${ }^{10}$ Cities in Transylvania such as: Reghin, Sighişoara, Oradea, Timișoara, Cluj and Sebeș.
} 
Congress of the Romanian Communist Party in August 6-12, 1969. ${ }^{11}$ Thus, the Committee of Ministers of the Socialist Republic of Romania adopted in 1970 the "Decision on the Organization and Functioning of the Central Commission for the Systematization of Rural and Urban Localities and Local Systemic Commissioning Committees 12 " which prepared by the end of the year the "Project of the National Program of Systematization of the Territory and Localities." According to the directives elaborated at the $10^{\text {th }}$ Congress of the Romanian Communist Party and the National Conference in 1972, "the multilaterally developed socialist society" in the making was closely linked to the systematization of the cities and villages, fact that created good conditions in the state's distribution of

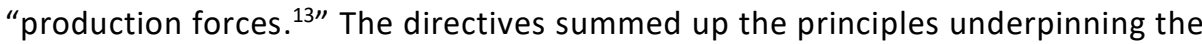
systematization of the territory, supporting the social equality regardless of the ethnic origin of the inhabitants.

In these circumstances, the General Assembly (Marea Adunare Națională) adopted "Law No. 58/ October 29, 1974 on the systematization of urban and rural localities and settlements ${ }^{14 "}$ and "Law No. 37/ November 20, 1975 on the systematization, design and construction of traffic arteries in urban and rural localities. ${ }^{15 "}$ "The laws officiated the provisions of the "Directives of the 11th Congress of the Romanian Communist Party" in 1974:16 "One of the essential guiding principles of the systematization process will be to ensure equal living conditions for all citizens of the country, regardless of their nationality, in the spirit of the principles of socialist equity, the gradual eradication of the essential differences between cities and villages by raising the village at the level of development of the city. ${ }^{17 \prime \prime}$ The guidelines for the systematisation of the villages was a central part of the programme. It stressed the importance of a policy of development, concentrating investments to localities considered to have had good development prospects. Construction of houses and service units were to be allowed only in villages with good

11 See also: Ilarion Țiu, "Ceaușescu și problema sistematizarii rurale" in Sfera politicii, Vol. XXII, No. 2 (178), March- April 2014, p. 9-16, available at:

http://www.sferapoliticii.ro/sfera/178/art02-Tiu.php (Last access: May 2017).

12 Official Bulletin of the Socialist Republic of Romania, No. 87, July 20, 1970.

13 Official Bulletin of the Socialist Republic of Romania, No. 79-80, July 23, 1972.

${ }^{14}$ See full text at: Official Bulletin of the Socialist Republic of Romania, No. 135, November 1, 1974.

${ }^{15}$ See full text at: Official Bulletin of the Socialist Republic of Romania, No. 123, November 26, 1975.

16 During the $11^{\text {th }}$ Congress of the Romanian Communist Party was adopted the "Romanian Communist Party Program for the Formation of Multilaterally Developed Socialist Society and the Advancement of Romania towards Communism".

$17 * * *$, Programul Partidului Comunist Român de făurire a societăţii socialiste multilateral dezvoltate şi înaintare a României spre comunism (Bucharest: Editura Politică, 1975), 85. 
development projections; small ones and those with scattered houses were to gradually be depopulated. ${ }^{18}$

Regarding the systematization policy during the 1970s in Transylvania, Ceauşescu's regime applied a policy of placing Roma in nationalized and confiscated Saxon houses. Housing distribution was made both by the enterprises the people were working at, or by the City Halls, more specifically by the Dwelling Offices. Usually, in order to receive a house at least one of the family members had to be employed, but there were made some exceptions when families who lived in harsh conditions, especially those with many children, according to Law No. 5 of 28 March 1973, received housing immediately. Thus, many Roma families received houses in the centre of some former Saxon cities such as Reghin, Sighişoara or Bistrița in change of a monthly rent.

The phenomenon of urbanization and urban systematization is a reality that affected millions of citizens, regardless of ethnicity, who witnessed the transformation of the localities dwelled at the time, amid both the forced industrialization and the artificial growth of the demographic mass. Even though the systematisation program was not set up specifically to destroy Roma housing, Roma neighbourhoods ended up razed and Roma were forcibly settled either in large apartment buildings or in improvised dwellings. The Helsinki Watch Report published in 1991 stated that Roma were targets of Ceauşescu's systematization program, which called for the razing of whole districts and the construction of modern apartment buildings in their place. The report added that the systematization policy in Romania rarely accomplished the intended positive effect on the Roma housing situation, frequently its results turned actually to be devastating. Yet, considering the interviews recorded during the fieldwork campaigns ${ }^{19}$ in different cities in Transylvania, the urban development policies failed after all in terms of the inability of the communist authorities to completely erase Roma neighbourhoods within urban landscapes and change that "parasitic lifestyle" of Roma communities living across Romania at the time. Since many of those neighbourhoods were formed during the interwar years, they were, according to the official ideology, the product of the exploitation of the Roma minority by the capitalist elites. Given the ideological principles of the communist regime these spaces should have been of utmost importance for their project of addressing social injustice in the Romanian society. This was, as the following paragraphs come to show, never the case. For the first two

18 Per Ronnas, Urbanization in Romania. A geography of social and economic change since independence (The Economic Research Institute Stockholm School of Economics, 1984), 65.

19 The research leading to these results has received funding from EEA Financial Mechanism 2009-2014 under the project contract no. 14SEE/30.06.2014, "Untold Story. An Oral History of the Roma people in Romania"; Beneficiary Institution: Babeș-Bolyai University, Oral History Institute, Cluj-Napoca. A number of 623 interviews have been recorded within different Roma communities in Romania. 
decades of the communist rule there was no clear nationwide policy specifically targeting Roma neighbourhoods. Indeed, the systematization process started in the late 1950s lead to the demolition of several Roma neighbourhoods in different cities in Romania, but these were consequences of the general policies of urban planning at the time, which focused on the reconfiguration of the city centres and the building of micro-districts at the periphery. It was only in 1977 that several measures aimed specifically at the Roma were drafted by the communist leadership under the direction of Nicolae Ceaușescu. ${ }^{20}$

\section{Living a parasitic lifestyle. Reports on the Roma population in communist Romania}

The communist regime ordered fieldwork campaigns within Roma communities living in Romania during the 1950s, in order to determine an image of their numbers as well as relevant features regarding the nomadic, semi-nomadic and the sedentary Roma communities. By the 1970s, the communist regime managed to complete to a certain extent the sedentarisation of the nomadic Roma communities in Transylvania. Yet, as plenty documents in the Archives ${ }^{21}$ stated and many of the Roma interviewees testified, several Roma communities continued in a way or another to travel and sell goods. Even if these Roma communities had stable addresses, they continued to practice semi-nomadism until the end of the communist period and/ or even during the 1990s. In order to tighten up control upon this semi-nomadic population, during the 1970s the Communist Party sought to limit vagrancy, begging and "parasitic lifestyle", and elaborated several decrees which implicitly targeted the semi-nomadic Roma and also the Roma living at the periphery of several settlements. In this sense, "Decision No. 2291/ December 15, 1969 for establishing contraventions on public order" sanctioned the practice of begging with a fine of 100 to 300 Lei if "appealing to public charity for getting material help to people who have possibilities maintenance, and by people who are able to work. ${ }^{22 "}$ This decision was to be repealed and replaced by "Decree No. 153/

20 Călin-Andrei Olariu, "We, too, were there! Roma people's remembrance of the Socialist City. Space, Memory and Oral History" in Stan L., Halfdanarsson G. (Eds.), Untold Stories. Oral histories of the Roma People in Romania, in print.

${ }^{21}$ According to a study carried out in 1976 by the bodies of the Ministry of the Internal Affairs and the National Demography Commission, the Roma population of the Socialist Republic of Romania included about 541.000, out of which 474.530 sedentary Roma, 66.000 seminomadic Roma and 470 nomadic Roma. See also: The Documentary Fond of the National Council for Studying the Securitate Archives (further ACNSAS), "Study on the economic and social situation of the Gypsy population in our country", Dossier No. 144, Vol. 15, f. 1-11.

${ }^{22}$ Article 1.d. in Decision No. 2291/ December 15, 1969, available at:

http://lege5.ro/Gratuit/g44dcnjq/hotararea-nr-2291-1969-pentru-stabilirea-si-sanctionareaunor-contraventii-privind-ordinea-si-linistea-publica?d=2017-06-01 (Last access: May 2017). 
March 24, 1970 on the establishment of contraventions on the rules of social co-habitation, public order and tranquillity. ${ }^{23 "}$ Apparently, the law portrayed a benign regulation of the public space with rules and responsibilities for all citizens. This Decree enshrined in Article 1 the contraventions for such actions: one to six months of imprisonment or a fine of 1.000 to 5.000 Lei for actions such as: begging, prostitution, gambling and practicing a parasitic lifestyle. Regarding the last one, Article 1.d. stipulated that groups of people who "by their behaviour expressed a parasitic or anarchic life conception, contrary to the principles of socialist coexistence ${ }^{24 \prime}$ were to be fined according to the law in force. Later, another law stipulated the offense of "having / living a parasitic lifestyle": "Law No. 25/ November 5, 1976 regarding the employment in the labour force of persons able to work". The preamble states the rights and responsibilities of each Romanian citizen to work in the socialist country and contribute to its progress.

According to reports written during the 1970s, parasitism was considered a "life concept" of the Roma population. This way of life was to be completely eliminated due to the measures adopted by the socialist regime. A study on the economic and social situation of the Roma population in Romania in the 1970s was completed in 1977 and conducted in the previous years by representatives of the National Commission for Demography, the Ministry of Education, The Ministry of Internal Affairs, The Ministry of Labour, The Ministry of Health, as well as representatives of the General Prosecutor's Office. The program of housing construction and systematization of localities led to a faster social integration of the Roma population, the disappearance of some Roma insalubrious neighbourhoods, and implicitly, the improvement of their living conditions. Yet, the second half of the 1970s presented a large Roma population living in unsanitary conditions: in tents, huts, dwellings built out of mud with no access to light - all of them forming the periphery of different settlements (cities and villages).

The report emphasized the poor sanitary status of various Roma communities, fact that was considered to be a "real danger" for other citizens who frequented the markets, fairs or crowded areas Roma frequented at the time. Another issue highlighted in the study was that of illiteracy and Roma reluctance in sending their children to school, and in this sense the documents made reference especially to the nomadic and semi-nomadic groups who continued to practice their traditions considered to be a "parasitic concept of life" which generated and perpetuated the highly offensive status of these communities. Their "social non-integration" is ascribed to the central and local authorities who applied

\footnotetext{
${ }^{23}$ See full text at: Decree No. 153/ March 24, 1970, in Buletinul Oficial (Official Bulletin), No. 33, April 13, 1970.

${ }^{24}$ Article 1.d in Decree No. 153/ March 24, 1970, in Buletinul Oficial (Official Bulletin), No. 33, April 13, 1970.
} 
insufficient measures meant to change the "backward life concepts" Roma had, by sending them, in most of the cases, from one county to another. In applying sedentarisation measures, the local authorities have dealt in many ways with the nomadic communities. Firstly, nomadic Roma communities had been sent to "the county of their origin", where the local authority was supposed to deal with their cause. Sometimes they settled immediately, but in many cases such as those presented before, it was actually a lengthy process. Apparently, according to the study drafted in 1977, travelling around the country, there was a number of 5.512 nomadic and semi-nomadic Roma who showed: "[...] a behaviour which is contrary to the rules of the social co-habitation and who are leading a parasitic way of life. ${ }^{25 "}$

The reports in 1977 also made references to the Roma sedentary communities who lived in difficult promiscuous conditions as well, most often at the periphery of the locality, in Roma neighbourhoods, and caused "various problems" due to their increased criminal status. With respect to the social integration of the Roma population and for the sake of removing parasitism, the report proposed that the central and local authorities take several measures to address the following issues: the sedentarisation of the Roma semi-nomadic families, their employment and their enrolment in schools. ${ }^{26}$ Thus, the Committees and the Executive Bureaus of the Popular Councils were advised to support, according to the systematization plan of the localities, the allocation of land for housing construction, long-term credits or housing from the state fund for the Roma population in that locality, and to consider starting the demolition of the unsanitary housing occupied by Roma in different areas. In this sense, health authorities must have drawn records of unsanitary homes in order to perform monthly medical and sanitary checks in the areas inhabited by Roma populations. The local authorities were also recommended to avoid placing Roma population in compact neighbourhoods, because of the negative influence on the young population, and to place them, where possible, in rural areas. Among the facts describing the parasitic lifestyle of the Roma, the study noted several cases of "flagrant violation of the rules of social co-habitation and disruption of public tranquillity" 27 committed by Roma people. Thus, according to the documents in the archives, due to the "parasitic lifestyle" of a part of the Roma population, their frequent violations of the social co-habitation rules and the conflicts between Roma and other ethnicities, the Communist Party had to take immediate actions against

25 Serviciul Arhive Nationale Istorice Centrale (further ANIC), Fund "Comitetul Central al Partidului Comunist Român", Secţia organizatorică, "Informare privind unele probleme pe care le ridică populaţia de ţigani din ţara noastră. 1978", Dossier No. 25, f. 5.

${ }^{26}$ ACNSAS, Documentary Fund, "Study on the economic and social situation of the Gypsy population in our country", Dossier No. 144, Vol. 15, f. 135.

27 ANIC, Fund "Comitetul Central al Partidului Comunist Român", Secţia organizatorică, "Informare privind unele probleme pe care le ridică populaţia de ţigani din ţara noastră. 1978", Dossier No. 25, f. 2. 
the Roma. This is, most often, the main justification of several actions the communist authorities did against Roma compact neighbourhoods, beginning with the 1960 s and continuing in the 1970s and 1980s.

One of the themes addressed in the study prepared in 1977 was the number of Roma citizens in Romania during the communist period, its evolution in time, adding some projections for the number of this population at the end of the twentieth century. The study presented a chart $^{28}$ signed by the President of the National Demography Commission and the Minister of Internal Affairs, which was introduced within the confidential document entitled: "Proposals for filling in the Report on the social-economic situation of the Gypsy population in Romania." This document showed the concerns of the National Demography Commission: the inability to issue a total number of the Roma population who was living in Romania in the 1970s. Data regarding the numbers of Roma were most of the times as different as conflicting: if the National Census in 1966 recorded a number of 64.197 Roma, the one in 1977 a number of 229.986, the research completed by the Ministry of Internal Affairs revealed in 1971-1972 a number of approximately 1.3 million Roma and for 1976 it recorded a number of 541.000. On the other hand, other sources, namely the Institute of Political Sciences and Studies of the National Problem and the Centre for Sociological Research of the University of Bucharest recorded a total number of 1.7 million Roma. An excerpt of the content of the document was copied in the Helsinki Watch Report in 1991, which wrote that: "in relation with the population they live together with, there is a much higher birth rate among Gypsies. For instance, in Mureş County between 1965 and 1974 the total number of children born rose 1.5 times, while the number of children born in Gypsy families rose almost 10 times. There are large Gypsy populations in the following counties: Mureş, Alba, Sibiu, Brașov etc. the Gypsies usually live in compact groups, at the outskirts of villages, or in peripheral districts of towns. ${ }^{29 \prime \prime}$ In these circumstances, the most urgent issue raised by this confidential document was the growth of the Roma population by the end of the twentieth century, and along with it, "the amplification of the negative consequences generated by the parasitic social behaviour of the Gypsies. ${ }^{30 "}$ The content of the document showed the demographic evolution of the Roma population under the law in force ${ }^{31}$ prohibiting the

28 ACNSAS, Documentary Fund, "Study on the economic and social situation of the Gypsy population in our country", Dossier No. 144, Vol. 15, f. 141.

29 Helsinki Watch Report, Destroying ethnic identity. The persecution of Gypsies in Romania, September 1991, Helsinki Watch, HU, OSA, 341-0-1, Box 31, Publications of the Human Rights Watch, 109.

30 ACNSAS, Documentary Fund, "Proposals for filling in the 'Report on the social-economic situation of the Gypsy population in Romania'”, Dossier No. 144, Vol. 15, f. 223.

31 "Decree No. 770/ October 1, 1966 to regulate the interruption of pregnancy" published in Official Bulletin No. 60, October 1, 1966 which became Law 36/1966. 
interruption of pregnancy among Romanian women, stating that Roma women use less surgical interruptions of pregnancies compared to Romanian women who practice abortion on a large scale, both legally and clandestinely. These statements $^{32}$ show in fact how limited was the communist central authorities' knowledge regarding the practices of abortion within the Roma communities. In this sense, most of the interviewees with Roma women who remembered their lives during the communist regime, mentioned or remembered and told in details their or other women experiences related to the law of abortion, namely the manner in which most Roma women did clandestine abortions in order to limit the number of births, because their difficult economic situation at the time. The testimonies recorded several memories related to Roma women who died trying to put an end to their pregnancy, or in more fortunate cases, were taken to the hospital with severe complications and after released, they were subjected to endless inquiries by the authorities, some ending up in prisons for a period of time.

In the "Note on the research reports in 1979" carried out by the Centre for Sociological Research in Bucharest, Nicolae Gheorghe ${ }^{33}$ wrote about the social isolation of the Roma in Romania in relation to the communities within/ at the periphery they lived, a situation created, he wrote, by "the historical past of this population, the class inequalities and the ethnic stratification of the Romanian society before $1944 .{ }^{34 \prime \prime}$ It further noted that the fieldwork research showed that the access of the Roma population to resources, offered by the socialist modernization, was unequal compared to that of other social groups within the communities in which they lived. Moreover, Nicolae Gheorghe highlighted the important differences between the Roma communities living in Romania at the time - this is the first time such statement appeared within the communist documents and reports regarding the Roma communities. Each time the author of any document wanted to refer to Roma, would have used the phrase: "Gypsy population", or simply the term "Gypsies", but never Roma communities or community. This document shows the interests Nicolae Gheorghe was promoting at the time in his attempt towards an official recognition of the Roma as a national minority, attempts that struck the opposition of the communist authorities in the

32 ACNSAS, Documentary Fund, "Proposals for filling in the 'Report on the social-economic situation of the Gypsy population in Romania'", Dossier No. 144, Vol. 15, f. 221-223.

${ }^{33}$ Nicolae Gheorghe was a Roma sociologist who worked during the communist period at the Centre for Sociological Research in Bucharest, and who became one of the best-known Romanian Roma activist.

${ }^{34}$ ACNSAS, Documentary Fund, "Note on the research reports in 1979", Dossier No. 144, Vol. 15, f. 67. 
past but which, given the accentuated nationalist character of the Ceaușescu's regime, had a viable chance of success. ${ }^{35}$

\section{Roma in Transylvanian cities during communism: housing and the everyday life}

In the context of the industrialization, urbanization and systematization of the urban and rural space in Transylvania during the communist period, Roma population was, in several cases, under the attention of the local and national authorities that made decisions related to their housing conditions. In this sense, the implementation of the systematization policy led to the disappearance of many houses considered insalubrious, to the remodelling of several districts, the enlargement of the traffic arteries and the construction of new working neighbourhoods at the peripheries of several cities. As mentioned above, one could observe two issues that led to changes in terms of residence of Roma communities during the communist era: on the one hand, the alert urbanization and industrialization process that required an urgent development of the urban space in terms of housing and, on the other hand, the communist regime's "fight" against the parasitic lifestyle in all its forms as a factor which delayed the modernization of the socialist society in the making. The following paragraphs aim to emphasise the everyday lives of Roma in several Transylvanian cities during the communist period, such as Cluj, ${ }^{36}$ Timișoara, Reghin or Sebeș. Oral history interviews highlighted life stories in various Roma communities living at the periphery of the cities, the interviewees remembered the systematization process of the cities in question, the destruction of some neighbourhoods, the annexation of several villages to cities, the procedure of getting a house during the communist regime, the everyday lives in Roma neighbourhoods, the discrimination they endured, as well as the relationship with the communist authorities etc.

In 1960, the Third Congress of the Romanian Communist Party held in Bucharest adopted the "Five Year Plan for the Development of the Economy (19601965)" as well as a presumptive long-term plan for the following 15 years, representing in fact an extension of the policies adopted after 1956. In order to improve the living standard of the working class, it was decided to gradually increase wages, to improve housing conditions, to increase funding for education, to provide better social care and to build a new infrastructure in the sanitary system. ${ }^{37}$ Regarding the systematisation process in the 1970s and the forced urbanisation of several villages in Romania, post 1989 historiography shows that the distinction between the city and "the rural world" was never clearly marked: socialist cities

\footnotetext{
${ }^{35}$ See also: Manuela Marin, "Un prieten devotat nouă: Ioan Cioabă și Securitatea comunistă" in Lucian Vasile, Constantin Vasilescu, Alina Urs (Eds.), Traversând comunismul. Conviețuire, conformism, compromis (Iasi: Editura Polirom, 2016), 361-383.

36 The name of the city has been Cluj-Napoca since 1973.

37 Călin-Andrei Olariu, "Urban construction patterns in the city of Cluj, 1952-1965" ...
} 
"swallowed" several villages, often by demolition. In this respect, the city of ClujNapoca witnessed in the 1970s a physical expansion along with the population growth, with the arrival of the workers. The industrial areas of the city were accompanied by the emergence of housing districts in various other areas. In this context, the urbanization of the Mănăştur neighbourhood was registered as an example of the new socialist space. The discourse related to the urbanization process of Mănăştur neighbourhood claimed that it was a Romanian village at its origin and degenerated because of the Roma population who settled there in the meantime. Therefore, the discourse stated that Mănăştur was "poor and Gypsy," fact that justified its demolition. For the authorities, the demolition appeared as a "civilizing action": those who received homes in the apartment buildings were to improve their low standard of living. It is interesting to note that, despite the fact that architects made reference of the Roma area in Mănăştur as being the poorest one and therefore susceptible to demolition, the first demolitions concerned the Romanian area. ${ }^{38}$

According to Gabriel Troc, Romanian anthropologist who wrote about the systematisation policy in Mănăştur, there can be established two distinct periods in its metamorphosis: the first period starting in the mid-1960s and ended around 1972 which, in terms of urban development, showed some concern for the principles of the modern habitat: there were relatively large spaces between the apartment buildings, with children's playgrounds, green spaces, alleys and quick access to the means of transport. The second period, which began around 1975 and lasted until the fall of the communist regime, abandoned those principles. The scheme of the systematisation of the cities and villages involved an intensive use of urban spaces: therefore, under the pressure of the last wave of industrialization, the urbanization of Mănăştur was under the sign of improvisation. In this second period, most of the old village was demolished, inclusively the Roma colony living along a river, in an area considered by the former villagers to have been the western border of Mănăştur. Along with the demolitions, in Mănăştur was built one of the main streets/ arteries of Cluj-Napoca and of the new neighbourhood: Primăverii Street. ${ }^{39}$

One of the fieldwork campaigns in Cluj County was held in the village of Florești, situated in the immediate vicinity of the today's Mănăştur neighbourhood. The oral history interviews were recorded within the Baptist Roma community in the village, and many of the Roma families living there lived at some point in the city of Cluj-Napoca. Interviewee Stela Hoca was born in the village of Mănăştur and spent

38 Dominique Belkis, Gabriela Coman, Corina Sîrbu, Gabriel Troc, "Construirea urbană, socială și simbolică a cartierului Mănăștur" in Ideea. Arta si societate, No. 15-16, 2003, available at: http://www.idea.ro/revista/?q=ro/node/40\&articol=185 (Last access: May 2017).

39 Gabriel Troc, "'După blocuri' sau despre starea actuală a cartierelor muncitorești” in Ideea. Arta si societate, No. 15-16, 2003, available at:

http://www.idea.ro/revista/?q=ro/node/40\&articol=184 (Last access: May 2017). 
her childhood in her parents' house on the Lingurarilor Street, the above-mentioned Primăverii Street. The interviewee remembered, with nostalgia, the years she and her family lived in the village of Mănăştur:

"We warmed up with wood, our father made the fire, he brought the wood with his carriage. A good householder gathers everything, you know. (...) We had a horse and a carriage. And then, after they demolished the house, he [the father] sold them because he couldn't use them anymore. That was it! But it was very nice, our life! (...) We had a garden, we had everything, we had seedlings to one side, and on the other side we had beans, corn, we had potatoes. ${ }^{40 \prime \prime}$

Another interviewee in Florești spoke about her childhood at her grandparents' house in the village of Mănăştur, where she spent the years before she went to school. She remembered Mănăştur as being situated "right in the centre of the city of Cluj 41 " - she stated that the neighbourhood was "more like a village," and only after a couple of years the apartment buildings were constructed. She did not remember the status of Mănăştur before it was attached to Cluj-Napoca during the 1970s, but she made reference to the fact that many Roma families lived in houses in this neighbourhood, and more came and settled there to work in the factories in the city the years following.

During the 1970s, after several houses were razed, the apartments in the newly built blocks were distributed either directly to people whose houses had been demolished but also to those people who worked in factories in Cluj-Napoca. Article 9 in Law No. 5 of March 28, 1973 stipulated that citizens whose dwellings were demolished for new constructions or systematization were to receive with rent a dwelling from the state-owned fund until they built or bought a dwelling. The amount of money for the demolished dwelling was to be considered the advance for the new dwelling they were to build or buy. Interviewee Stela Hoca remembered the moment in which their house, along with the other ones on the Lingurarilor Street was demolished:

"They demolished our house. The State. All the houses were demolished and apartment buildings were built instead. And we received a dwelling, we got an apartment (...) we received so little

\footnotetext{
40 Stela Hoca, interview by the author, audio file, no. 1036, OHIA, Florești, Cluj County, January 22, 2015.

${ }^{41}$ C.Q., interview by Ionela Bogdan, audio file, no. 1039, OHIA, Florești, Cluj County, January 22, 2015.
} 
in comparison to what we had. (...) Well, after that, I worked, I worked at garment factory Flacăra, then I got married and I applied and received an apartment from the factory, (...) a threeroom apartment in the same neighbourhood of Mănăştur. ${ }^{42 "}$

Most of the interviews recorded with Roma who remembered their habitation during the communist period in blocks of flats recalled the good relations with their neighbours and, most of the time, to the advantages they had as workers in obtaining a home during the communist period, regardless of its location in the perimeter of the locality in which they lived. Nostalgic testimonies regarding the communist regime included most of the times the housing distribution policy and the "advantages" the working people could have benefited. All interviewees made reference to the ways in which they obtained a dwelling during Ceauşescu's era. One of the Roma interviewees ${ }^{43}$ in the city of Reghin remembered that during the communist period she was a member of the Communist Party, participated at the Party's meetings in Reghin and attended Ceaușescu's visit at the inauguration of a new factory in the city. She remembered that she had a colleague who had filed a request for a dwelling at the factory, but who was put on a waiting list. During the inauguration of the factory, he approached Nicolae Ceaușescu who signed the dwelling request - this was, the interviewee explained, an act of courage, but without which the local authorities would have postponed his request for as long as they wanted. Many other interviewees have invoked the manner in which they received dwellings during the communist regime and many of them stated that there were no people, who were enrolled in a stable workplace, and did not receive housing if they applied. Provided to Law No. 5 of March 28, 1973 renting of the dwellings from the state housing fund was to be made in the following priority order: "the skilled workers from the large industrial units; staff transferred from other localities; specialists working in material production, design, scientific research and education; graduates in production coming from other localities; families with many children; those who earned their workplace by competition, coming from other localities; other employees and pensioners. ${ }^{44 "}$ Moreover, according to the same Law, within the above categories, priority was to be given to people with difficult living conditions, especially to those with many children and low incomes. This was the

\footnotetext{
42 Stela Hoca, interview...

43 Lucica Chiriac, interview by lonela Bogdan, audio file, no. 1447, OHIA, Reghin, Mureş County, September 7, 2015.

44 Law No. 5/ March 28, 1973 "On the management of the housing fund and the regulation of relations between owners and tenants", available at: http://lege5.ro/Gratuit/he2dinjv/legeanr-5-1973-privind-administrarea-fondului-locativ-si-reglementarea-raporturilor-dintreproprietari-si-chiriasi/ (Last access: June 2017).
} 
manner in which many Roma families received housing in the nationalised Saxon houses in the centre of the city of Reghin.

In particular cases, Roma people were employed in the state factories, but the communist authorities did not intervene in regard to their housing placed in marginal districts, often showing difficult living conditions. In this regard, the Roma neighbourhood in Sebes remained a compact district since the communist period, and apparently it was omitted from the systematisation plans, even though Sebes became a strong industrial city during the communist regime in Transylvania. In the case of Sebeș, it seems that the communist authorities in the city managed to apply a "social integration" of the Roma community who adopted several changes in terms of "the rules of work and social co-habitation 45 " without dislocating or dispersing them as it was managed in other cities. Here, Roma people were employed in the city's factories as long as one of the main characteristics of the communist regime was the policy implemented in order to promote a so-called equity between workers and to provide jobs to all citizens. In this sense, Roma interviewees in Sebeș, regardless of their formal education level, were hired in different factories and thus, as many of them testified, they felt they were treated with respect as long as their workplaces offered them stability and status in society. ${ }^{46}$ Yet, according to the oral history interviews recorded there, the housing distribution was repeatedly discriminating Roma people even though they had families with children and, of course, a stable workplace. According to the interviews recorded in the Roma neighbourhood in Sebeș, ethnic discrimination was applied during the socialist state's housing distribution. Even though some Roma employees at the woodworking factory received housing in Kogălniceanu neighbourhood, Roma employed in other factories in the city were rejected under various reasons from receiving a dwelling in the newly built blocks of apartments. Margareta lancu remembered that she got married and lived for a period of time in the small house of her parents-in-law together with her husband's family and her first child. In those circumstances, as long as she worked at the Ciserom factory and her husband was also employed, she applied for a dwelling at the Ciserom factory. Immediately afterwards, a social investigation was carried out in order to determine the reasons for which the lancu family was to receive housing from the state fund. Finally, she remembered they did not receive an apartment on the request at the factory, but on the waiting lists at the City Hall where they applied as well - yet, they refused that

45 ACNSAS, Documentary Fund, "Study on the economic and social situation of the Gypsy population in our country", Dossier No. 144, Vol. 15, f. 2.

46 See Ionela Bogdan, "A Life Story is Also a Serious Business. Feminine Narratives during Communist years in the Town of Sebeș" in Annual of Oral History, No. XVI - The Roma in Romania: Sharing a Traumatic past- Living in a problematic present (Cluj-Napoca: Argonaut, 2015), 74-89. 
particular dwelling for it was "filled with mould," and therefore they remained to live in the Roma neighbourhood where they nowadays have a house of their own.

Another Roma neighbourhood which remained untouched by the systematization policy of the cities and villages is the Kuncz district in Timișoara. Part of the neighbourhood is inhabited entirely by Roma and forms "one of the most dangerous areas of the city since the communist era. ${ }^{47 \prime}$ The area on which the district is located appears to have belonged to an owner of a bricks factory that, during the interwar period, allowed mostly Roma ethnics to settle there in some barracks on the lands near the factory. After the Second World War, the area was nationalized, but people continued to live there, with the district expanding its size in the 1970s. The Roma population in the neighbourhood is, as the locals described the situation, divided into two groups: on the one hand, "the natives", namely the Roma who inherited their homes before WW2 and, on the other hand, "the newly arrived Roma" who came in large numbers to live there during the communist era, especially during 1971-1975, coming after some family members had already settled there in the 1960s. According to the interviewees who live in the neighbourhood of Kuncz, Roma migrated to Timișoara due to the very difficult life conditions they had at their home places. Beyond this division of the Roma population in the neighbourhood, there is also a clear distinction made by the native Roma between the behaviours of the two groups: "new natives" who "lived in a beautiful Kuncz, surrounded by beautiful waters, had trees painted in chalk near their clean houses ${ }^{48}$ " and, on the other side, "the Roma who came later" and who "did not bring anything better than we [the natives] had here, but created a complete disaster. ${ }^{49 "}$ " One of the most interesting particularities of the Roma communities who live in this neighbourhood is that most of them do not own identity papers (birth certificates and identity cards) and do not own any papers on the dwellings and the lands they are inhabiting. In the context in which during the communist period the control of the state authorities was rigorous, it is interesting to unravel the reason for which the population in Kuncz neighbourhood was overlooked by the authorities. According to the interviews recorded in the neighbourhood, there were a few issues that somehow offered a plausible explanation: apparently, the local authorities did not take any measures in this regard, even if they were aware of the situation of the locals there, many of whom were employed and had a "worker's card" at one of the factories in Timisoara. In this understanding, the main interest of the communist authorities was that people from this neighbourhood must have been engaged in permanent work.

47 Alexandru Virag, interview by Sînziana Preda, audio file, no. 1176, OHIA, Timişoara, Timiș County, July 16, 2015.

48 Liuba Fus, interview by Sînziana Preda, audio file, no. 1175, OHIA, Timişoara, Timiș County, July 16, 2015.

${ }^{49}$ Alexandru Virag, interview... 


\begin{abstract}
"In front of the park [in the neighbourhood] there was a Militia bus, and when everybody went to work in the morning, they were legitimating every person. The interesting part, to me at least, is that they didn't ask the men for their identity cards but only for the worker card [...] who didn't have cards and were not employed anywhere, were put in the bus and, according to the laws back then, were sent to prison for three to six months. ${ }^{50 \prime}$
\end{abstract}

Thus, it seems that local authorities knew about the lack of identity documents in the Kuncz neighbourhood. Apparently, people who settled in the neighbourhood during the 1960s and 1970s had no identity cards or birth certificates, and therefore they were unable to obtain their children identity papers. ${ }^{51}$ However, the local authorities applied a "careful observation" on this population mostly because the image of the Kuncz neighbourhood, as Roma interviewees remembered, had become a negative one in Timișoara since the 1960s: "The neighbourhood was the most famous in terms of crime and other bad things and it was recognized as the 'black sheep' of the locality, just like it is today. ${ }^{52 "}$ According to Alexandru Virag, everyone could have applied for a dwelling at the factory where they were hired and the housing distribution office would have granted flats in Timișoara without doing any kind of discrimination, mostly because the people in Kuncz were displayting "the most dramatic situations" in terms of habitation.

Apparently in the late 1980s the Kuncz neighbourhood was closely regarded by the national and local authorities in the view of its demolition. As mentioned above, the land on which the houses were placed in the neighbourhood was nationalized along with the wave of nationalizations undertaken at the beginning of the communist period. Thus, the systematization plan of the city of Timișoara included the massive demolition of these illegally built dwellings on the state's land and the construction of a series of blocks for workers, as long as some of the factories in the locality were operating in the vicinity of Kuncz and represented an important attraction for the labour force. The question to which no clear answer can be given, remains why was the systematization of this neighbourhood postponed until the late 1980s, although it was clearly a "black spot" and a "parasitic centre" of one of the most representative cities in Transylvania. Nowadays, this episode

\footnotetext{
$50 \mathrm{lbid}$.

51 In Romania, the birth certificate is issued only on the basis of the following documents: the mother's identity card and birth certificate, the father's identity card and birth certificate (if he recognizes the child) and the marriage certificate (if any).

52 Alexandru Virag, interview by the author, audio file, no. 1655, OHIA, Timişoara, Timiș County, June 7, 2017.
} 
represents one of the stories which create a strong link among the community of the neighbourhood, as the population is constantly talking about the demolition of Kuncz and about the "blessing" of the 1989 Revolution for the entire community of this district.

\begin{abstract}
"Unless the 1989 Revolution happened, the Kuncz neighbourhood was to be completely demolished in the spring of 1990. Yes. Our luck was the Revolution, and thus the demolition did not happen. And then, the consequences we would have suffered... because this neighbourhood was going to become an arable land. ${ }^{53 \prime}$
\end{abstract}

\title{
Conclusions
}

In conclusion, according to the Communist Party's Program, the systematization process implemented especially in the 1970s and 1980s was meant to change the daily life of peripheral communities, ensuring a place of social equity, a totally different space from the one that the bourgeoisie created during the interwar period. The slums, or the insalubrious neighbourhoods were to totally disappear and all inhabitants of the socialist cities would have gained equal access to educational, medical, recreational or transport services, regardless of their location, in the centre or at the outskirts of those settlements. The situation of these peripheral communities, which, according to Communist authorities, were living a parasitic life, needed to be urgently and irrevocably changed in terms of their habitat, by employing them in factories, by obliging their children to attend school, and other measures the local authorities had to implement towards the "social integration" of these groups into the socialist society in the making. However, as different cases in Cluj-Napoca, Sebeș or Timișoara showed, the decisions were made according to urbanization and city planning system, some demolitions of Roma peripheral districts being sometimes postponed or even not taken under consideration. Looking at the situation of the Roma neighbourhoods placed at the outskirts of the mentioned cities, those demolished were those that were located on the land which, according to the systematization plans, was to be used to build the working quarters, and thus, regardless of the population living in that perimeter, they had been evacuated and moved. However, in the case of the Sebeș Roma community living on the outskirts of the city, no actions were made to systematize that particular territory. The same situation was registered with the Kuncz neighbourhood in Timișoara (where apparently the demolition was scheduled for the 1990s) where the situation of the inhabitants, mainly of Roma ethnicity, was controlled under the form of their "gradual integration" into the communist society by fulfilling the above-

53 Ibid. 
mentioned standards. Thus, there was no urgency regarding the modernization of those neighbourhoods.

Finally, even though during the communist period in Romania the Roma communities were not recognized as an ethnic minority, one can depict specific policies aiming "to change" the Roma communities' tradition, behaviour and dwelling conditions - all of which were considered to be a "parasitic lifestyle," blamed by the socialist state. The systematisation policy, closely linked to the sedentarisation process, was one of the measures that brought specific changes within some of the Roma people's housing conditions during the communist period. However, despite these measures, according to the historiography and also to the fieldwork campaigns conducted for the present research, the peripheral poor dwelling conditions of the Roma in Romania and particularly in Transylvania continued to exist during the aftermath of the 1989 Revolution. 